\title{
PEMBUATAN BAHAN POLIMER ELEKTROLIT PADAT BERBASIS NANOKOMPOSIT KITOSAN MONTMORILLONITE UNTUK APLIKASI BATERAI
}

\section{(SYNTHESIS OF SOLID POLYMER ELECTROLYTE BASED ON CHITOSAN MONTMORILLONITE NANOCOMPOSITE FOR BATTERY APPLICATION)}

\author{
Evi Yulianti ${ }^{1}$, Rosiana Dwi Saputri ${ }^{2}$, Sudaryanto ${ }^{1}$, H. Jodi ${ }^{1}$, dan R. Salam ${ }^{1}$ \\ ${ }^{1)}$ Pusat Teknologi Bahan Industri Nuklir (PTBIN)-BATAN \\ Kawasan Puspiptek Serpong, 15314, Tangerang. \\ ${ }^{2)}$ Jurusan Fisika-FMIPA Universitas Jenderal Sudirman, Purwokerto \\ E-mail : yulianti@batan.go.id
}

Received: 4 Juni 2013; revised: 10 Juni 2013; accepted: 11 September 2013

\begin{abstract}
ABSTRAK
Telah dilakukan pembuatan bahan polimer elektrolit padat berbasis nanokomposit kitosan montmorillonite yang diaplikasikan dalam sistem baterai. Penelitian ini dilakukan dengan tujuan untuk menentukan komposisi optimal antara kitosan, montmorillonite dan $\mathrm{LiClO}_{4}$ sehingga diperoleh membran dengan karakteristik yang paling baik. Teknik pembuatan membran dilakukan menggunakan metode casting. Terdapat dua seri sampel yang akan di uji, yaitu membran dengan variasi komposisi montmorillonite dan variasi komposisi $\mathrm{LiClO}_{4}$. Komposisi kitosan dan montmorillonite yang digunakan pada sampel seri kedua diperoleh dari komposisi optimal membran kitosanmontmorillonite pada sampel seri pertama. Karakterisasi yang dilakukan meliputi uji tarik, pengukuran konduktivitas ionik dan identifikasi menggunakan difraksi sinar X. Penambahan montmorillonite meningkatkan kuat tarik membran dan konduktivitas ionik setelah ditambah $\mathrm{LiClO}_{4}$. Pada kondisi optimal diperoleh konduktivitas ionik $2,383 \times 10^{-5} \mathrm{~S} / \mathrm{cm}$ dan kuat tarik 15,19 Mpa pada komposisi montmorillonit $5 \%$ b/b dan $\mathrm{LiClO}_{4} 40 \%$. Hasil analisis difraksi sinar $X$ menunjukkan terjadi proses interkalasi polimer kitosan ke dalam montmorillonite.
\end{abstract}

Kata kunci : nanokomposit, kitosan, montmorillonite, polimer elektrolit

\begin{abstract}
Synthesis of Solid Polymer Electrolyte (SPE) based on chitosan montmorillonite nanocomposite has been done. In the future SPE will be applied in battery system. This research was conducted to determine the optimum composition of chitosan, montmorillonite and $\mathrm{LiClO}_{4}$ in order to get the the best characteristic membrane, including conductivity and mechanical properties. The membranes were prepared by casting method. There were two sample series, chitosan and montmorillonite and chitosan-montmorillonite and $\mathrm{LiClO}_{4}$ with different compositions. The nanocomposite chitosan-montmorillonite membranes were characterized their conductivty, tensile strength and crystal structure by high precision LCR, Universal Testing Machine (UTM) and X-ray diffraction (XRD), respectively. The experimental result shows that the addition of montmorillonite increase in tensile strength and ionic conductivity after the addition of lithium salt $\mathrm{LiClO}_{4}$. Overall, the optimum condition was obtained at composition 5\% montmorillonite and $40 \% \mathrm{LiClO}_{4}$. This composition has the conductivity and tensile strength about $2.383 \times 10^{-5} \mathrm{~S} / \mathrm{cm}$ $=$ and $15.19 \mathrm{MPa}$, respectively. XRD analysis proved the intercalation of polymer chitosan into the montmorillonite layers.
\end{abstract}

Keywords : nanocomposite, chitosan, montmorillonite, polymer electrolyte 


\section{PENDAHULUAN}

Maraknya penggunaan perangkat elektronik
seperti handphone serta laptop/netbook mendorong para ahli untuk mengembangkan alternatif sumber penyimpanan energi. Baterai merupakan salah satu sumber penyimpanan energi yang paling efektif. Baterai terdiri dari dua komponen penting yaitu elektrolit dan elektroda. Elektrolit atau konduktor ionik berperan sebagai jembatan untuk mentransfer ion-ion yang dihasilkan oleh elektroda. Pada awalnya elektrolit berbentuk cairan, namun elektrolit cair memiliki kekurangan diantaranya kurang praktis, mudah bocor dan mudah korosi. Oleh karena itu orang beralih kepada elektrolit bermatriks padatan sebagai elektrolit baterai. Membran elektrolit padat yang ideal harus memiliki stabilitas kimia, stabilitas termal konduktivitas proton yang tinggi, fleksibilitas tinggi, biaya yang rendah dan ketersediaan bahannya yang melimpah di alam (Yuan, et al. 2009 ; Fonseca, and Neves 2006).

Berbagai jenis material terus dikembangkan dalam pembuatan elektrolit padat baterai. Penggunaan polimer sintetis sebagai bahan elektrolit padat ternyata masih memiliki beberapa kekurangan. Selain harganya yang mahal, dampak lingkungan akibat menumpuknya sampah kimia juga menjadi salah satu permasalahan yang sering muncul. Kembali ke alam merupakan solusi yang paling di rekomendasikan untuk mengatasi masalah tersebut. Kitosan merupakan salah satu jenis polimer alam yang berpotensi sebagai bahan elektrolit padat. Kitosan adalah biopolimer karbohidrat alam yang diturunkan dari proses deasetilasi kitin. Kitin sendiri merupakan senyawa biopolimer kedua yang paling banyak ditemukan dialam setelah selulosa(Rinaudo, 2006; Muzzareli and Muzzareli 2005; Yahya and Arof 2003). Penelitian elektrolit padat dengan bahan dasar kitosan telah banyak dilakukan (Yahya and Arof 2003; Kadir et al. 2011; Shujahadeen et. al. 2010). Salah satunya adalah fabrikasi film elektrolit padat berbasis kitosan menggunakan teknik implantasi ion. Konduktivitas ionik membran yang dihasilkan masih relatif rendah yaitu sekitar $10^{-7} \mathrm{~S} / \mathrm{cm}$ (Yulianti, et al. 2012). Selain itu fabrikasi bahan elektrolit padat dengan cara menambahkan garam lithium ke dalam matriks kitosan menggunakan metode casting juga masih memiliki kekurangan. Kebanyakan garam-garam yang ditambahkan bersifat higroskopis sehingga berpengaruh dalam aplikasi serta sifat mekanik yang kurang bagus pada daerah konduksi (Munshi, 1995).
Berbagai usaha telah dilakukan guna mendapatkan bahan elektrolit padat yang memiliki konduktivitas tinggi, stabilitas mekanik dan fleksibilitas tinggi. Salah satu upaya yang banyak saat ini adalah dengan menyisipkan nanomaterial ke dalam matriks polimer. Material baru ini disebut dengan Polymer/clay nanocomposite (Kurian et al. 2012) Clay memiliki struktur lembaran, dimana jarak antar lembarannya berada pada orde nanometer. Partikel-partikel berukuran nanometer memiliki luas permukaan interaksi yang tinggi. Interaksi yang maksimal antara matriks polimer dengan nanopartikel akan menghasilkan pola pendispersian yang merata pada matriks polimer. Konfigurasi ini menyebabkan perubahan yang signifikan terhadap sifat fisis bahan yang dihasilkan. Keunggulan material ini antara lain meningkatkan kekuatan, kekakuan, kestabilan dimensi dan resistensi terhadap suhu tinggi. Salah satu jenis clay yang banyak dipelajari saat ini adalah montmorillonite. Sejumlah hasil penelitian menunjukan bahwa penambahan montmorillonite ke dalam matriks polimer terbukti mampu meningkatkan sifat mekanik material yang dihasilkan (.Kusmono 2010; Hartono 2011).

Berdasarkan uraian di atas, pada makalah ini dilaporkan hasil penelitian mengenai pembuatan dan kajian konduktivitas ionik serta kuat tarik bahan nanokomposit polimer kitosan dan monmorilonit yang kemudian ditambah dengan garam lithium berupa Lithium Perklorat $\left(\mathrm{LiClO}_{4}\right)$ dengan tujuan untuk mendapatkan bahan polimer elektrolit berbasis kitosan dengan konduktivitas ionik dan sifat mekanik yang lebih baik.

\section{BAHAN DAN METODE}

\section{Bahan}

Bahan yang digunakan pada penelitian ini adalah kitosan dari kulit kerang produksi Institut Pertanian Bogor dengan nilai derajat deasetilasi sebesar $86 \%$, asam asetat $1 \%$, montmorillonite $\mathrm{K}$ 10 (Sigma-Aldrich), lithium perklorat $\left(\mathrm{LiClO}_{4}\right)$ (Sigma-Aldrich) dan aquades.

\section{Metode}

Pada penelitian ini dibuat dua seri sampel. Untuk sampel seri pertama diawali dengan pembuatan nanokomposit kitosan-montmorillonite. Proses pembuatan membran nanokomposit dilakukan menggunakan metode casting. Langkah pertama adalah melarutkan kitosan ke dalam asam asetat 1\%. Larutan kemudian didiamkan selama 3 hari 3 malam sambil sesekali diaduk sampai terbentuk larutan yang bening. 
Langkah selanjutnya adalah menambahkan montmorillonite ke dalam matriks kitosan dengan variasi komposisi $2 \%, 5 \%, 10 \%, 15 \%$ dan $20 \%$ dalam persen berat. Larutan kitosan ditambahkan montmorillonite kemudian diaduk menggunakanmagnetic stirrer selama kurang lebih dua jam sehingga terbentuk larutan yang homogen.

Selanjutnya masing-masing komposisi (kitosan + montmorillonite) ditebarkan di atas plat kaca dan dimasukkan ke dalam pengering sampai terbentuk membran. Sampel yang dihasilkan kemudian dikarakterisasi untuk mengetahui komposisi yang paling optimum.

Selanjutnya, sampel seri kedua diperoleh dengan cara menambahkan garam $\mathrm{LiClO}_{4}$ ke dalam campuran larutan kitosan dan montmorillonite. Variasi komposisi garam yang ditambahkan yaitu 5\%,10\%, 20\%, 30\% dan $40 \%$ (dalam persen berat). Komposisi kitosan dan montmorillonite yang digunakan diperoleh dari komposisi optimum membran nanokomposit kitosan-montmorillonite pada sampel seri pertama. Dengan teknik yang sama maka diperoleh membran nanokomposit kitosan montmorillonite dengan variasi komposisi garam lithium. Membran nanokomposit yang dihasilkan kemudian dikarakterisasi kembali untuk mengetahui perubahan sifat fisis akibat penambahan garamgaram lithium.

Karakterisasi yang dilakukan meliputi konduktivitas ionik, kuat tarik dan kristalinitas membran. Kekuatan tarik diuji menggunakan alat Universal Testing machine (UTM) strograph VGS S-E Toyoseiki berdasarkan American Standard Testing and Material (ASTM) D-1822 L. Konduktivitas ionik membran diukur menggunakan LCR Hi-tester Hioki 3532-50. Identifikasi fasa dan kristalinitas sampel di karakterisasi menggunakan peralatan Shimadzu X-Ray Diffractometter XD610.

\section{HASIL DAN PEMBAHASAN}

1. Analisis Konduktivitas ionik membran
Kitosan
Nilai konduktivitas ionik membran nanokomposit kitosan-montmorillonite yang diukur dengan berbagai variasi frekuensi ditunjukkan pada Gambar 1. Nilai frekuensi yang digunakan adalah pada rentang $42-10^{6} \mathrm{~Hz}$.

Pada Gambar 1 secara umum terlihat bahwa konduktivitas ionik membran mengalami kenaikan dengan kenaikan frekuensi. Selain itu juga terlihat bahwa penambahan montmorillonite ke dalam matriks polimer kitosan tidak memberikan perubahan yang signifikan terhadap konduktivitas ionik membran dimana pada rentang frekuensi 42 $\mathrm{Hz}-1 \mathrm{MHz}$, nilai konduktivitas membran mengalami kenaikan berkisar pada $10^{-10}-10^{-7}$.

Nilai konduktivitas yang terukur dapat dibedakan menjadi dua yaitu konduktivitas $A C$ dan konduktivitas $D C$. Konduktivitas $A C$ adalah konduktivitas yang nilainya dipengaruhi oleh perubahan frekuensi, sedangkan konduktivitas $D C$ merupakan konduktivitas yang nilainya tidak dipengaruhi oleh perubahan frekuensi, pada sampel ini terjadi pada kisaran frekuensi rendah (42- $150 \mathrm{~Hz}$ ). Nilai konduktivitas DC untuk masingmasing membran ditunjukan pada Tabel 1. Konduktivitas $D C$ diperoleh melalui hasil fitting garis pada kurva hubungan antara nilai konduktivitas dan frekuensi yang mengikuti persamaan Universal Power Law (UPL): $\sigma(\omega)=$ $\sigma_{\mathrm{dc}}+A \omega^{\mathrm{n}}$ (Pradan 2008), sehingga dapat diketahui pengaruh penambahan montmorillonite terhadap konduktivitas $D C$ membran (film) kitosan.

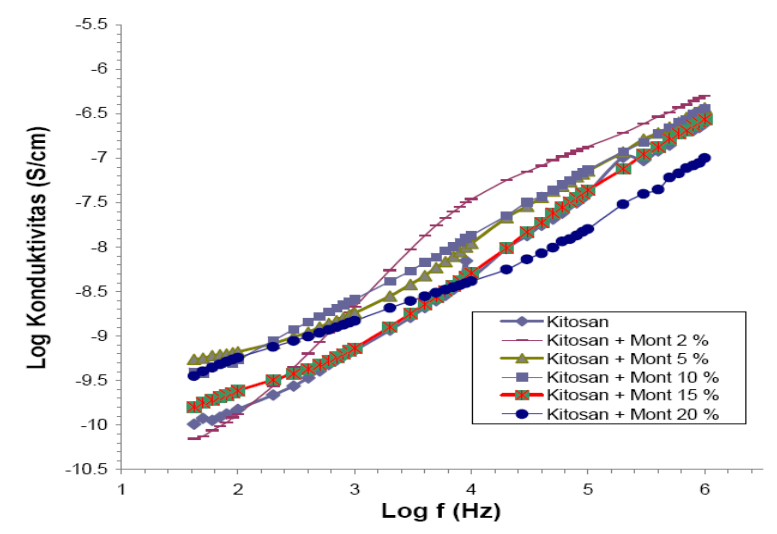

Gambar 1. Pengaruh frekuensi pada konduktivitas ionik membran kitosan pada variasi penambahan Montmorillonite

Tabel 1: Konduktivitas $D C$ membran kitosan dengan penambahan montmorillonite pada berbagai komposisi.

\begin{tabular}{lcc}
\hline No. & $\begin{array}{c}\text { Komposisi } \\
\text { montmorillonite }(\%)\end{array}$ & Konduktivitas dc \\
\hline 1. & 0 & $8,16 \times 10^{-10}$ \\
2. & 2 & $2,60 \times 10^{-10}$ \\
3. & 5 & $5,18 \times 10^{-10}$ \\
4. & 10 & $2,29 \times 10^{-10}$ \\
5. & 15 & $2,74 \times 10^{-10}$ \\
6. & 20 & $5,66 \times 10^{-10}$ \\
\hline
\end{tabular}


Berdasarkan data pada Gambar 1 dan Tabel 1 terlihat bahwa nilai konduktivitas ionik membran untuk berbagai variasi komposisi montmorillonite masih berada pada orde $10^{-10}$. Penambahan montmorillonite tidak meningkatkan nilai konduktivitas secara signifikan dikarenakan struktur dari montmorillonitei walaupun kaya akan ion-ion seperti $\mathrm{Al}$ atau $\mathrm{Mg}$ tetapi ionnya terikat dalam bentuk senyawa koordinasi dalam struktur oktahedral (Hartono 2011). Konduktivitas ionik kitosan awal yaitu sebesar $8,16 \times 10^{-10} \mathrm{~S} / \mathrm{cm}$. Nilai konduktivitas ionik membran cenderung mengalami penurunan setelah ditambah montmorillonite. Penurunan nilai konduktivitas ionik terjadi saat komposisi montmorillonite $2 \%$ yaitu sebesar $2,60 \times 10^{-10} \mathrm{~S} / \mathrm{cm}$. Penurunan ini disebabkan karena adanya penggumpalan (aglomerasi) yang justru akan menghalangi loncatan atau transport ion pada membran. Ini terlihat dari hasil gambar mikroskop optik yang dapat dilihat pada Gambar 2.

Penambahan garam Lithium Perklorat $\left(\mathrm{LiClO}_{4}\right)$ dilakukan guna meningkatkan nilai konduktivitas ionik bahan. Komposisi $\mathrm{LiClO}_{4}$ yang ditambahkan adalah 5\%,10\%, 20\%, 30\% dan 40 $\%$ berat dari polimer kitosan. Hasil pengukuran konduktivas ionik membran dengan variasi komposisi garam lithium disajikan pada gambar 3 dan Tabel 2.

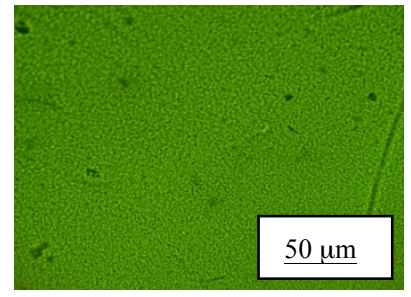

a

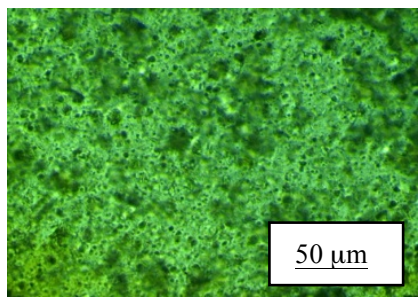

b
Gambar 2. Hasil mikroskop optik membran a). kitosan dan b). kitosan + montmorillonite

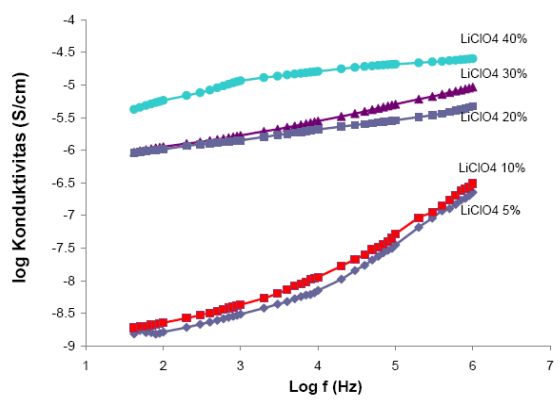

Gambar 3. Pengaruh frekuensi terhadap konduktivitas ionik membran kitosan/montmorillonite pada variasi komposisi $\mathrm{LiClO}_{4}$
Tabel 2: Konduktivitas DC membran kitosan / montmorillonite dengan penambahan $\mathrm{LiClO}_{4}$ pada berbagai komposisi

\begin{tabular}{lcc} 
No. & Komposisi $\mathrm{LiClO}_{4}(\%)$ & Konduktivitas dc \\
\hline 1. & 5 & $1,43 \times 10^{-9}$ \\
2. & 10 & $3,05 \times 10^{-9}$ \\
3. & 20 & $4,79 \times 10^{-7}$ \\
4. & 30 & $5,16 \times 10^{-7}$ \\
5. & 40 & $2,38 \times 10^{-5}$ \\
\hline
\end{tabular}

Dari Gambar 3. dan Tabel 2. terlihat secara umum terjadi perubahan nilai konduktivitas setelah ditambah garam $\mathrm{LiClO}_{4}$. Nilai konduktivitas ionik membran setelah ditambah $\mathrm{LiClO}_{4}$ mengalami perubahan yang sangat signifikan dari nilai konduktivitas awal sekitar $10^{-10}$ menjadi $10^{-5}$ Konduktivitas membran mengalami kenaikan hingga 100.000 kali lipat. Kenaikan konduktivitas ionik setelah penambahan garam lithium dikarenakan permukaan yang kaya akan ion - ion lithium yang dimiliki oleh membran. Semakin banyak komposisi garam yang ditambahkan, konduktivitas ionik membran juga semakin meningkat. Hal ini berarti semakin banyak ion yang bergerak akibat penambahan garam lithium dalam membran. Secara keseluruhan nilai Konduktivitas optimum diperoleh pada komposisi $\mathrm{LiClO}_{4} 40 \%$ yaitu sebesar $2,38 \times 10^{-5} \mathrm{~S} / \mathrm{cm}$.

\section{Analisis Kuat Tarik membran Kitosan}

Kekuatan tarik berperan penting terhadap sifat mekanik nanokomposit polimer yang dihasilkan. Kekuatan tarik di ukur dari besarnya gaya maksimum yang digunakan untuk memutuskan/mematahkan spesimen awal bahan dengan luas penampang tertentu

Pada penelitian sebelumnya (Costa, et. al 2010), penambahan garam $\mathrm{LiClO}_{4}$ pada fabrikasi membran kitosan dengan teknik casting ternyata menghasilkan sampel yang bersifat higroskopis. Penambahan garam justru menyebabkan sampel menjadi rapuh dan lembek sehingga tidak memungkinkan untuk dilakukan uji tarik. Pada penelitian ini telah ditambahkan montmorillonite ke dalam matriks kitosan guna meningkatkan kekuatan mekanik membran. Dari hasil karakterisasi uji tarik, dapat diketahui pengaruh penambahan montmorillonite pada berbagai komposisi terhadap kekuatan tarik nanokomposit polimer yang ditunjukan pada Gambar 4. 


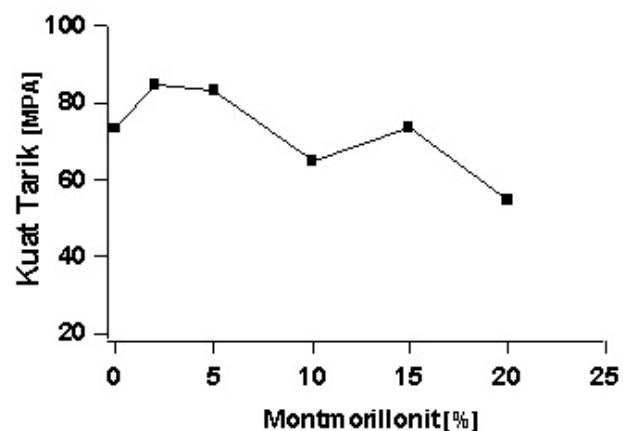

Gambar 4. Pengaruh penambahan montmorillonite terhadap kuat tarik film kitosan.

Pengaruh penambahan montmorillonite terhadap nanokomposit polimer yang dihasilkan ditunjukan pada Gambar 4. Tampak bahwa penambahan montmorillonite mampu meningkatkan kekuatan tarik nanokomposit. Peningkatan kuat tarik disebabkan karena sifat dasar montmorillonite yang memiliki kekakuan tinggi sehingga membatasi gerakan molekul polimer. Luas kontak permukaan struktur nanokomposit yang besar juga menyebabkan ikatan yang kuat antara matriks polimer kitosan dengan lapisan montmorillonite. Kuat tarik optimum diperoleh pada komposisi montmorillonite 5\% yaitu sebesar 93,1 MPa.

Pada Gambar 4 juga terlihat adanya penurunan kuat tarik nanokomposit. Penurunan terjadi saat penambahan konsentrasi montmorillonite 10\% yaitu sebesar 64,98 MPa. Penurunan kuat tarik disebabkan adanya aglomerasi montmorillonite. Penggumpalan ini menyebabkan terbentuknya daerah antarmuka (interface) atau daerah kosong antara kitosan dan montmorillonite. Hal ini disebabkan karena montmorillonite yang dicampur masih berupa serbuk sedangkan kitosan yang berperan sebagai pengikatnya sudah dalam bentuk larutan. Adanya daerah yang kosong, ketika sampel nanokomposit ditarik akan lebih cepat patah dan bersifat lebih getas. Hasil ini serupa dengan penelitian yang dilakukan oleh Rudi Hartono yang melakukan penambahan montmorillonite pada matriks polipropilen (Hartono 2011).

Pengaruh penambahan $\mathrm{LiClO}_{4}$ terhadap besarnya kuat tarik membran juga dianalisis. Pengaruh penambahan garam lithium terhadap kuat tarik membran disajikan pada gambar 4 .

Berdasarkan hasil pengukuran rata - rata kekuatan tarik membran diperoleh bahwa semakin

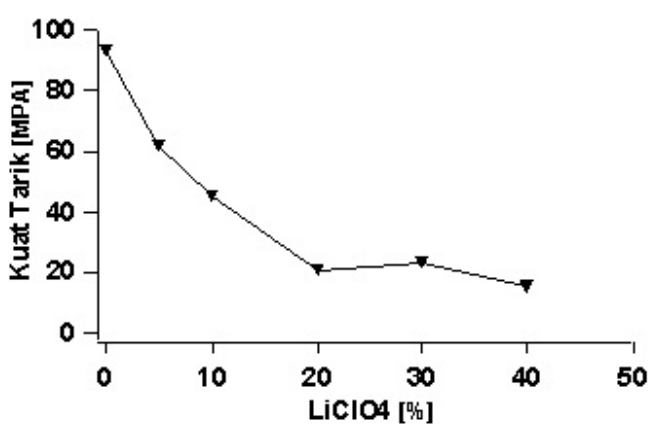

Gambar 5. Pengaruh penambahan $\mathrm{LiClO}_{4}$ terhadap kuat tarik membran kitosan montmorillonite

banyak $\mathrm{LiClO}_{4}$ yang ditambahkan maka nilai kuat tarik membran semakin menurun.

Peningkatan jumlah $\mathrm{LiClO}_{4}$ akan menurunkan kekuatan gaya antar molekul sehingga mobilitas antar rantai molekul kitosan meningkat. Hal ini memungkinkan $\mathrm{LiClO}_{4}$ yang merupakan molekul higroskopis kecil dapat dengan mudah masuk diantara rantai - rantai polimer. Penurunan kuat tarik ini kemudian merubah sifat rigid membran menjadi lebih fleksibel. Fenomena di atas merujuk kepada hasil penelitian yang dilakukan oleh Taufik Nurkalih bahwa penambahan garam $\mathrm{LiClO}_{4}$ dalam matriks polimer PEO juga menurunkan kuat tarik membran yang dihasilkan (Nurkalih, 2009) Penurunan kuat tarik juga berkaitan dengan perubahan kristalinitas yang dimiliki oleh polimer akibat penambahan garam. Material yang amorf tentunya akan memiliki kekuatan mekanik yang lebih rendah dibandingkan dengan material yang bersifat kristalin. Penambahan garam $\mathrm{LiClO}_{4}$ telah merubah struktur polimer kitosan yang bersifat semikristalin menjadi lebih amorf. Perubahan struktur polimer ditunjukan pada pola difraksi yang disajikan pada Gambar 6.

\section{Identifikasi Pergeseran Puncak Difraksi dan Kristalinitas Membran Kitosan- Montmorillonite}

Identifikasi pergeseran puncak difraksi dan kristanilitas membran dikarakterisasi menggunakan $X R D$. Selain itu analisis $X R D$ dilakukan untuk memonitor pembentukan nanokomposit. Hasil karakterisasi $X R D$ disajikan dalam bentuk pola difraksi yang ditampilkan pada Gambar 6 dan Gambar 7 


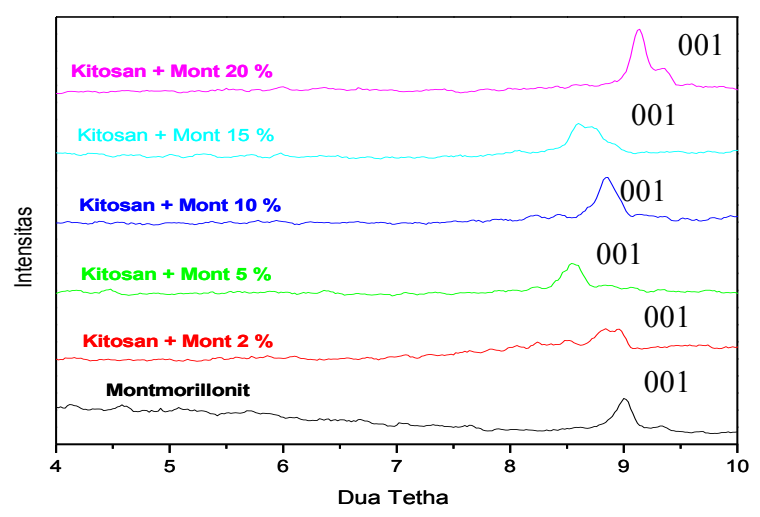

Gambar 6. Pola difraksi membran nanokomposit polimer kitosan-montmorillonite

Gambar 6 menunjukan pola difraksi sinar-X untuk montmorillonite dan kitosan + montmorillonite dengan berbagai komposisi yang diukur pada sudut 2 theta $(3-15)^{\circ}$. Puncak montmorillonite muncul pada sudut 2 theta $8,96^{\circ}$ merupakan puncak refleksi pada bidang 001 dimana jarak antar bidang $\left(\mathrm{d}_{001}\right) \quad 9,87 \AA$ yang dihitung menggunakan persamaan Bragg (Cullity 1978). Pada Gambar 6 ditunjukkan bahwa terjadi sedikit pergeseran puncak - puncak difraksi ke arah sudut yang lebih rendah pada film kitosan + montmorillonite dengan komposisi (2-15)\%. Hal ini menunjukkan terjadi interkalasi polimer ke dalam antar lapisan montmorillonite. Salah satu atau beberapa rantai polimer berhasil masuk atau menyisip di antara lapisan montmorillonite yang jaraknya berada pada orde nanometer. Akibatnya jarak antar kisi pada montmorillonite menjadi semakin besar. Pola ini menunjukkan terbentuknya nanokomposit. Sedangkan pada penambahan montmorillonite lebih lanjut (20\%) ternyata menggeser puncak 001 ke sudut yang lebih besar. Hasil ini sesuai dengan penelitian yang telah dilakukan oleh Dillip K. Pradhan mengenai pembuatan membran nanokomposit dengan menambahkan montmorillonite pada matriks polimer PEO (Pradhan 2008).

Gambar 7. merupakan pola difraksi kitosan dan kitosan yang telah ditambah montmorillonite dan garam $\mathrm{LiClO}_{4}$ pada berbagai komposisi. Pola difraksi kitosan (spektrum paling bawah) memiliki puncak-puncak yang tidak tajam pada posisi sudut 2 theta $11,97^{\circ}$ dan 18,52 dimana pola difraksi ini umumnya dimiliki oleh bahan yang bersifat semikristalin. Semakin banyak garam $\mathrm{LiClO}_{4}$ yang ditambahkan ke dalam matriks kitosan, tentunya akan mempengaruhi struktur kristal kitosan.

\section{DAFTAR PUSTAKA}

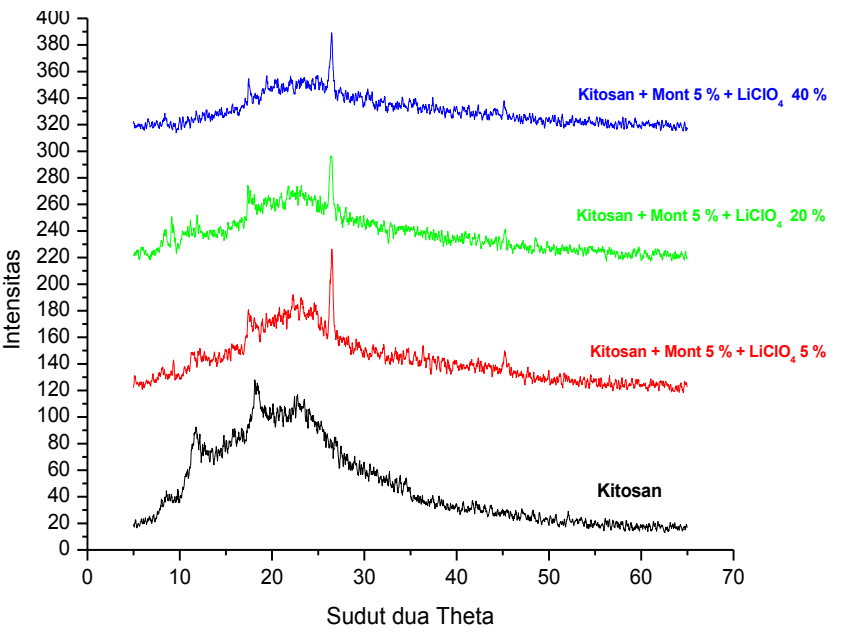

Gambar 7. Pola Difraksi Membran Nanokomposit Polimer Kitosan-Montmorillonite-LiClO 4 ( puncak montmorillonite, • : puncak kitosan)

Pada penambahan $\mathrm{LiClO}_{4}$ sebesar 20\% puncak kitosan sudut 2 theta $11,97^{\circ}$ tidak muncul, hanya tinggal satu puncak. Sedangkan pada penambahan $\mathrm{LiClO}_{4} 40 \%$, puncak kitosan hilang sama sekali, dan pola difraksi seperti ini biasanya dijumpai pada bahan yang bersifat amorf. Penambahan garam $\mathrm{LiClO}_{4}$ ke dalam matriks film kitosan telah mengubah struktur polimer yang bersifat semikristalin menjadi lebih amorf. Pada sudut dua tetha $27,05^{\circ}$ terdapat puncak yang sangat tajam. Puncak ini berasal dari silikat yang merupakan salah satu kandungan dari montmorillonite (Purwaningsih, et.al 2012).

\section{KESIMPULAN}

Telah berhasil dibuat membran polimer elektrolit berbasis nanokomposit kitosan montmorillonite. Berdasarkan penelitian yang telah dilakukan dapat diperoleh kesimpulan bahwa penambahan montmorillonite pada polimer kitosan sampai komposisi tertentu dapat meningkatkan kekuatan tarik film kitosan sampai 93,11 MPa. Selain itu penambahan garam $\mathrm{LiClO}_{4}$ juga terbukti dapat meningkatkan konduktivitas ionik film kitosan dengan sangat signifikan. Kondisi optimum diperoleh pada film nanokomposit kitosan dengan komposisi montmorillonite $5 \%$ persen berat dan $\mathrm{LiClO}_{4} \quad 40 \%$ dengan nilai konduktivitas ionik sebesar $2,382 \times 10^{-5} \mathrm{~S} / \mathrm{cm}$ dan kuat tarik sebesar $15,19 \mathrm{MPa}$. 
Aziz, S. B., Z.H.Z Abidin and A.K Arof. 2010. Effect of silver nanoparticles on the DC conductivity in chitosan silver triflate polymer electrolyte. Physica B 405 (21): 4429 - 4433

Costa, M.M., A.J. Terezo, A.L. Matos, W.A. Moura, J.A. Giacometti, and A.S.B. Sombra. 2010. Impedance spectroscopy study of dehydrated chitosan and chitosan containing $\mathrm{LiClO}_{4}$. Physica B: Condensed Matter 405 (21): 4439-444

Cullity, B.D. 1978. Elements of X-Ray Diffraction. Reading, Massachusetts -Menlo Park, California - London -Amsterdam - Don Mills, Ontario - Sydney: Addison-Wesley Publishing Company Inc.

Fonseca, C. Polo and S. Neves. 2006. Electrochemical properties of a biodegradable polymer electrolyte applied to a rechargeable lithium battery. Journal of Power Sources. 159: 712-716

Hartono, R. 2011. Pengaruh Komposisi Montmorillonite pada Pembuatan Polipropilen - Nanokomposit terhadap Kekuatan Tarik dan Kekerasannya. Prosiding Seminar Nasional Teknik Kimia, UGM. Yogyakarta.

Kadir, M.F.Z, Z. Aspanal, S.R Majid and A.K. Arof 2011. FTIR studies of plasticized poly(vinyl alcohol)-chitosan blend doped with $\mathrm{NH}_{4} \mathrm{NO}_{3}$ polymer electrolyte membrane. Spectrochimica Acta Part A 78 (3): 10681074

Kurian, M., M.E. Galvin, P.E Trapa, D.R Sadoway, and Mayes A.M. 2005. Single-ion Conducting Polymer-silicate Nanocomposite electrolytes for Lithium Battery applications. Electrochimica Acta 50: 2125-2134

Kusmono. 2010. Studi Kuat tarik Dan Morfologi Nanokomposit Berbasis Poliamid 6/Polipropilen/Clay. Seminar Nasional Tahunan Teknik Mesin (SNTTM) ke-9.UGM. Yogyakarta.
Munshi, M.Z.A. 1995. Handbook of Solid State Batteries and Capacitors. Singapore: World Scientific Publishing.

Muzzarelli, R.A.A and C. Muzzarelli. 2005. Chitosan chemistry: relevance to the biomedical sciences. Adv. Polym. Sci. 186: 151-209

Nurkalih, Taufik. 2009. Pembuatan Polielektrolit Padat untuk Aplikasi Baterai dari Polimer yang dapat Terbiodegradasi. Skripsi S1. Bandung: Departemen Kimia. FMIPA-ITB.

Pradhan, Dillip K., R. N. P. Choudhary, and B. K Samantaray. 2008. Studies of Dielectric Relaxation and AC Conductivity Behavior of Plasticized Polymer Nanocomposite Electrolytes. Int. J. Electrochem. Sci. 3(5): $597-608$

Purwaningsih, Eka, Supartono dan Harjono. 2012. Reaksi Transesterifikasi Minyak Kelapa Dengan Metanol Menggunakan Katalis Bentonit. Indo. J. Chem. Sci. 1 (2): 133-139.

Rinaudo, M. 2006. Chitin and chitosan: Properties and application. Prog. Polym. Sci. 31: 603632

Yahya, M.Z.A and A.K. Arof. 2002. Characteristics of Chitosan-Lithium Acetate-Palmitic Acid Complexes. Journal of New Materials for Electrochemical Systems 5(2): 123-128

Yahya, M.Z.A and A.K. Arof. 2003. Effect of oleic acid plasticizer on chitosan-lithium acetate solid polymer electrolytes. Eur Polym. J. 39: 897-902

Yuan, Xiao $\mathrm{Zi}$ et al. 2009. Electrochemical Impedance Spectroscopy in PEM fuell Cells. London, Dordrecth, Heidelberg. New York: Springer International Publisher.

Yulianti, E., A. Karo Karo, L. Susita, and Sudaryanto. 2012. Synthesis of Electrolyte Polymer Based on Natural Polymer Chitosan by Ion Implantation Technique. Procedia Chemistry 4: 202-207 